\author{
Dr.sc. Blanka Kačer, docentica \\ Pravni fakultet Sveučilišta u Splitu
}

\title{
O SLUČAJU MARIJE ŠARAPOVE (u svezi hrvatskog pravnog okvira odštetne odgovornosti)
}

\author{
UDK: 347 \\ Primljeno: 20.01.2018. \\ Pregledni rad
}

\begin{abstract}
U tekstu se pokušava pronaći prav(n)o rješenje jednog načelnog problema, ali uz analizu na konkretnom primjeru. U sučeljavanju dva neupitna, ali međusobno dijelom isključiva prava - s jedne strane pravo svih izraziti mišljenje nejavno i/ili javno (a to mišljenje ne mora ni u kojem slučaju biti pozitivno), s druge strane pravo svake osobe biti slobodna od bilo kakvih uvreda, kako javnih tako i nejavnih, što uključuje i iznošenje vlastitog stava koji vrijeđa drugoga potrebno je utvrditi granicu protupravnosti, o čemu ovisi koje pravo ima prednost. U konkretnom događanju je niz poznatih tenisačica javno protestirao (i tako radio pritisak na organizatore turnira) protiv davanja pozivnica za turnire igračici koja je upravo „odslužila“ svoju kaznu u trajanju od 15 mjeseci nenastupanja na turnirima, koja kazna je posljedica toga što je zatečena u kontroli nje kao sportašice i je li ona ili nije uzimala neki od preparata s liste zabranjenih. Nakon temeljite analize zaključeno je da je umjereno iskazivanje vlastitog mišljenja samo korištenje vlastitog prava na izražavanje svojeg mišljenja kojim se ne vrijeđa tuđa čast, niti ugrožava i oštećuje tuđe pravo osobnosti. Međutim, ako se pri tome pretjeruje onda je prijeđena granica - crta koja dijeli protupravna ponašanja od onih sukladnih pravu. U ovom drugom slučaju, ako su ispunjeni i ostali zakonski uvjeti, postoji građanskopravna odštetna odgovornost. U prvom slučaju, zato što je potrebno kumulativno ispunjenje svih uvjeta, ne postoji građanskopravna odštetna odgovornost.
\end{abstract}

Ključne riječi: pravna sigurnost, vladavina prava, jednakost pred zakonom, šteta, građanskopravna odgovornost.

\section{UVOD}

Cilj ovog rada je da, s jedne strane, jasno ukaže na postojeći načelni problem i jezgrovito izvrši analizu teme rada - pravnog okvira odštetne odgovornosti na konkretnom slučaju iz sporta, s druge strane, da na tom temelju opravdano privuče pozornost određene ,publike“ i čini nam se da smo (ovaj put) u tome prilično uspjeli.

Obzirom na vrijeme pisanja ovog teksta (drugi dio 2017. god.), jasno je da u prvom planu nisu teniski dosezi inače velike tenisačice Marije Sarapove ${ }^{1}$, već konkretno

1 Marija Šarapova je rođena u Rusiji 19. travnja 1987. god. U karijeri je samo od turnirskih nagrada osvojila 30 milijuna dolara (to su javno dostupni podaci, a smatra se kako je od sponzora zaradila višestruko više, ali to već nisu javni podaci). Pobijedila je na pet Grand Slam turnira. Svoj prvi Grand Slam, u Londonu (Wimbledon), osvojila je sa samo 17 godina 2004. god. Još je osvojila US OPEN 
Dr.sc. Blanka Kačer: O slučaju Marije Šarapove (u svezi hrvatskog pravnog okvira odštetne... Zbornik radova Pravnog fakulteta u Splitu, god. 55, 2/2018., str. 369.- 384.

jedan segment događanja oko te velike sportašice u svezi pronalaska nedopuštenih sredstava iz kategorije dopinga, radi kojih je proglašena krivom i kažnjena s 18 mjeseci zabrane nastupanja ${ }^{2}$. Za razliku od vjerojatno očekivanog, nećemo se u radu baviti time je li Mariju Šarapovu trebalo kazniti ili ne i, ako ju je trebalo kazniti, je li kazna pravilno određena. Predmet našeg interesa je vrijeme nakon izdržane kazne (u kojem razdoblju nije smjela nastupati niti na jednom teniskom turniru) jer postoje više nego jasni dokazi da se Mariju Šarapovu sustavno pokušava kažnjavati radi toga za što je već kažnjena i nakon izdržane kazne. Sporno jest je li takvo postupanje dopušteno ili nedopušteno, odnosno je li to dodatno kažnjavanje sui generis ili ne. U našem fokusu je eventualna građanskopravna odgovornost za štetu koja sama po sebi ne nameće niti isključuje kaznenopravnu odgovornost, kojom se u samom tekstu ne bavimo.

Ovaj problem je po svojoj naravi očito takav da je iznad bilo kakvih nacionalnih granica (neovisno jesu li to ruske granice po kriteriju državljanstva koji ima Marija Sarapova, američke po kriteriju dugogodišnjeg prebivališta Marije Šarapove, odnosno bilo koje države u kojoj je traženo dodatno „kažnjavanje“ Marije Šarapove, bilo na način da joj se uskrati tzv. Wild-card ${ }^{3}$, ili na način da se odredi za nastup na igralištima i u vrijeme koji ne znače neku pogodnost ${ }^{4}$.

Iako u Republici Hrvatskoj nismo registrirali takve aktivnosti ${ }^{5}$, hipotetično smo istražili kakav bi bio pravni status takve aktivnosti da je do nje došlo u Republici

2006. god., Australian Open 2008. god. i Roland Garros 2012. god. i 2014. god., te je jedna od samo dvije aktivne tenisačice (uz Serenu Williams) koje u svojoj kolekciji imaju sva četiri Grand Slam turnira u pojedinačnoj konkurenciji (a nema baš mnogo ni onih neaktivnih - konkretno to je sedam tenisačica abecednim redom: Maureen Connolly, Chris Evert, Steffi Graf, Doris. J. Hart, Billie Jean King, Martina Navratilova i Margaret Smith Court). Od aktivnih tenisačica od nje više (pojedinačnih) Grand Slam titula ima samo Serena Williams. Ima osvojena čak 36 WTA turnira, od čega jedan (Tijandin, Kina) u 2017. god., nakon izdržane kazne zbog doping skandala.

Tu kaznu je izdržala do proljeća 2017. god., kada je, što se WTA rang liste tiče, trebala krenuti „ab ovo“, dakle od početka. Početak znači igrati najmanje turnire, sakupljati bodove i tako se plasirati za one veće i tako redom, sve do mogućnosti igrati one najveće (Grand Slam) turnire. Oni koji nemaju dovoljno bodova ni za kvalifikacije za neki turnir, jedini izlaz im je dobivanje tzv. Wild card (pozivnice), za koju nisu potrebni bodovi, samo odluka organizatora.

3 Posebna pozivnica koja omogućava igraču, odnosno igračici nastup (u kvalifikacijama ili u glavnom turniru) neovisno o plasmanu na važećoj rang listi, koji taj nastup ne bi omogućio. Običaj je da se te pozivnice dijele prema kriterijima koji su autonomno pravo domaćina, odnosno organizatora. Poznati i dosta rašireni kriteriji su npr. mladi i perspektivni igrač ili igračica (posebno ako je iz tog grada ili države), interes sponzora, razmjena pozivnica (najpoznatije i gotovo institucionalizirane su između nacionalnih saveza koji su organizatori, praktično vlasnici Grand Slam turnira), bivši pobjednici, oni za koje se založi glavni sponzor, bivši pobjednici (npr. Goran Ivanišević je 2001. god. nastupio u glavnom turniru na Wimbledon-u kao trostruki finalist ranijih godina - plasman na ATP rang listi u tom trenutku: broj 125 - mu nije omogućio igranje glavnog turnira, koji je kasnije i osvojio kao prvi i jedini u povijesti s pozivnicom) i sl.

4 Npr. jedno je nastupati na glavnom igralištu na kojemu postoji pomični krov koji se aktivira u slučaju kiše, a drugo na bilo kojem drugom igralištu na kojemu kiša može, čak i više puta prekidati susret, jedno je biti na rasporedu nakon što sunce počne zalaziti (recimo ljeti u 19 sati), nego npr. u 11 sati ujutro kada npr. počinju susreti na Grand Slam turniru u Parisu - Roland Garros, jedno je dati igraču ili igračici minimalni odmor između dva susreta, a drugo „prebaciti“ susret na sljedeći dan itd.

5 Premda je jedan od najžešćih napada povezan baš s našom igračicom Mirjanom Lučić, koja već dugi niz godina živi u USA i (barem koliko je poznato) ne dolazi u Republiku Hrvatsku. 
Dr.sc. Blanka Kačer: O slučaju Marije Šarapove (u svezi hrvatskog pravnog okvira odštetne... Zbornik radova Pravnog fakulteta u Splitu, god. 55, 2/2018., str. 369.- 384.

Hrvatsko, odnosno uz primjenu hrvatskog pozitivnog prava. Obzirom na sličnost građanskopravne normative, posebno unutar država članica Europske unije, rezultati istraživanja su primjenjivi i daleko izvan granica Republike Hrvatske.

\section{PRAVNA VRELA}

Kao i glede bilo kojeg drugog pravnog pitanja, temeljno pravno vrelo je Ustav Republike Hrvatske, ${ }^{6}$ koji ima niz iznimno važnih odredbi za ljudska prava uopće, ali i za zaštitu mnogih drugih temeljnih prava. Obzirom na to da se radi o području građanskopravne odgovornosti, neovisno o tome što je to u svezi sporta, temeljno pravno vrelo nakon i pored Ustava je Zakon o obveznim odnosima, ${ }^{7}$ koji je sedes materiae glede te vrste odgovornosti. Isto značenje ima i Zakon o sportu $^{8}$ glede svakog pitanja u svezi sporta, pa tako i ovoga koje je predmet ovoga rada, neovisno o tome što sam ne sadrži odredbe o odštetnoj odgovornosti, nego se na ta pitanja na odgovarajući način primjenjuje Zakon o obveznim odnosima. Kako bi se opće odredbe Zakona o obveznim odnosima (koje nisu predlagane ni usvajane imajući u fokusu sport i sportsko pravo) mogle primijeniti na bilo koju imalo specijalnu situaciju i kako bi se moglo utvrditi je li netko postupao ili nije postupao lege artis u svezi sporta pravna vrela su i sve pravne norme koje spadaju u tzv. autonomno sportsko pravo. Obzirom na činjenicu da će se naknada štete (ne uvijek ${ }^{9}$, ali u pravilu) rješavati u parničnom postupku, bitno značenje i status pravnog vrela ima i Zakon o parničnom postupku ${ }^{10}$. Posebno pravno značenje imaju međunarodni ugovori, koji temeljem Ustava imaju nadzakonsku snagu pod uvjetom ratificiranja i objave. Ključni pravni akt u svezi dopinga u sportu je akt pod nazivom Svjetski antidoping kodeks - WORLD ANTI-DOPING CODE, ${ }^{11}$ koji je u primjeni od 01. siječnja 2015. god. ${ }^{12}$ Radi se o aktu koji je imao dvije ranije verzije dostupne na istoj web stranici,

6 Ustav Republike Hrvatske, NN 56/90, 135/97, 8/98 - pročišćeni tekst, 113/00, 124/00 - pročišćeni tekst, 28/01, 41/01 - pročišćeni tekst, 55/01, 76/10, 85/10 - pročišćeni tekst, 5/14 - dalje: Ustav.

7 Zakon o obveznim odnosima, NN 35/05, 41/08, 125/11, 78/15 - dalje: Zakon o obveznim odnosima ili ZOO.

8 Zakon o sportu, NN 71/06, 150/08, 124/10, 124/11, 86/12, 94/13, 85/15, 19/16 - dalje: Zakon o sportu ili ZOS.

9 Moguće su arbitraže, ali i najklasičnija izvansudska nagodba.

10 Zakon o parničnom postupku, SL 4/77, 36/77, 36/80, 69/82, 58/84, 74/87, 57/89, 20/90, 35/91, NN 26/91, 53/91, 91/92, 112/99, 117/03, 88/05, 2/07, 84/08, 96/08, 123/08, 57/11 i 148/11 - pročišćeni tekst, 25/13, 89/14 - dalje: Zakon o parničnom postupku ili ZPP.

11 WORLD ANTI-DOPING CODE 2015 - dalje: CODE ili CODE 2015. Vidjeti na: www.wada-ama. org. Treba naglasiti kako je u Republici Hrvatskoj u nakladi nacionalne anti - doping agencije (Hrvatski zavod za toksikologiju i antidoping - www.antidoping-hzta.hr) izdan hrvatski prijevod tog kodeksa čiji je nakladnik inače WORLD ANTI-DOPING AGENCY. Pored službenog teksta tu je i kratak komentar. Dalje: Kodeks.

12 U tijeku je rad na novom kodeksu koji se planira donijeti na godišnjem skupu koji će WADA imati u Katowicama (Poljska) na jesen 2019. god., s planiranim stupanjem na snagu 01. siječnja 2021. god. 
Dr.sc. Blanka Kačer: O slučaju Marije Šarapove (u svezi hrvatskog pravnog okvira odštetne... Zbornik radova Pravnog fakulteta u Splitu, god. 55, 2/2018., str. 369.- 384.

jednu iz 2003..$^{13}$, drugu iz 2009. god. ${ }^{14}$ Taj pravni akt u stvarnosti ima nadzakonsku snagu i predstavlja rijedak primjer takvog stanja, ${ }^{15}$ koje ima i prednosti i nedostatke. Među prednosti treba svrstati učinkovitost, a među nedostatke inverziju hijerarhije pravnih normi. Naravno, kada se radi o sportu i sportskom pravu, ne smijemo zaboraviti ni akte Međunarodnog olimpijskog odbora ${ }^{16}$, pored ostaloga i Olimpijsku povelju iz rujna 2004. god., dokumenta koji, pored ostaloga, u prvi plan stavlja „poštovanje univerzalnih temeljnih etičkih načela“ $i$,stvaranje mirnog društva koje nastoji očuvati ljudsko dostojanstvo" ${ }^{17}$. Taj podzakonski akt svoju pravnu snagu crpi iz Međunarodne konvencije protiv dopinga u sportu koja je usvojena 2005. god. u sjedištu UNESCO u Francuskoj (Pariz) i koja je stupila na snagu 01. veljače 2007. god., nakon što ju je ratificiralo 30 država sukladno njenom članku 37. Hrvatski sabor kao (državni) zakonodavac je Konvenciju ratificirao Zakonom o potvrđivanju Međunarodne konvencije protiv dopinga u sportu ${ }^{18}$. Uredbom Vlade Republike Hrvatske 2007. god. osnovana je Hrvatska agencija za borbu protiv dopinga u sportu (HADA). Godine 2010. novelom Zakona o sportu ${ }^{19}$ HADA se kao pravni subjekt ukida, te stupanjem na snagu Zakona o izmjenama i dopunama Zakona o zdravstvenoj zaštiti ${ }^{20}$ Hrvatskom zavodu za toksikologiju (HZT) pripajaju sve aktivnosti bivšeg pravnog subjekta HADA, te se naziv ustanove mijenja u Hrvatski zavod za toksikologiju i antidoping (HZTA). Nadležnost HZTA se temelji na odredbama novele Zakona o sportu iz 2010. i novele Zakona o zdravstvenoj zaštiti iz iste godine. U provedbi Kodeksa HZTA je donijela poseban Pravilnik za borbu protiv dopinga ${ }^{21}$ koji je publiciran u posebnoj publikaciji donositelja. Iako se ne radi o biti, nego i formi, ipak treba primijetiti da nije dobro što se navedeni pravilnik nije objavilo i onako kako se inače objavljuju podzakonski akti iza kojih svojim

13 WORLD ANTI-DOPING CODE 2003 - dalje: CODE ili CODE 2003.

14 WORLD ANTI-DOPING CODE 2009 - dalje: CODE ili CODE 2009.

15 U Republici Hrvatskoj se, kao i u većini država, primjena promjena koje donese WADA provodi putem domaćih podzakonskih akata, što ide vrlo brzo i učinkovito. Postoje međutim države (kao što je Spanjolska) gdje je to nadležnost zakonodavca, što dovodi do situacija kao što je kažnjavanje države od strane WADA jer neki propis nije implementiran, a u konkretnom slučaju nije implementiran jer zakonodavno cijelo nije (bilo) ustrojeno - oformljeno. Iako se ne radi o području dopinga, sličan modus operandi je zabilježen kada je FIFA naredila nogometnom savezi BiH da promijeni statutarnu odredbu o predsjedništvu (sastojećem od tri člana, po jedan predstavnik svakog konstitutivnog naroda - bosanskog, hrvatskog i srpskog) ustrojenom po analogiji s državnim Predsjedništvom (koje ne smeta ni UN-u, a očito ni EU), jer će u protivnom biti isključeno iz predstojećih kvalifikacija, eventualno i iz članstva. Naredba je promptno izvršena, a ostaje promišljati što bi se dogodilo da je „slučaj“ završio na europskim sudovima.

16 Međunarodni olimpijski odbor ili International olimpic committee - dalje: ili u punom nazivu ili skraćeno: MOO ili IOC.

17 Vidjeti više na: www.ioc.org.

18 Zakon o potvrđivanju Međunarodne konvencije protiv dopinga u sportu (Narodne novine, Međunarodni ugovori 07/2007 - dalje: Zakon o Konvenciji).

$19 »$ Narodne novine«, br. 124/10.

20 Zakon o zdravstvenoj zaštiti (»Narodne novine«, br. 150/08, 71/10, 139/10, 22/11, 84/11, 12/12, 35/12 - Odluka Ustavnog suda Republike Hrvatske, 70/12, 82/13 i 22/14 - Odluka Ustavnog suda Republike Hrvatske, 131/2017 - dalje: Zakon o zdravstvenoj zaštiti ili ZZZ).

${ }_{21}$ Pravilnik za borbu protiv dopinga (dalje: Pravilnih HZTA). 
autoritetom stoji država ${ }^{22}$, nego samo objavom na web stranici HZTA i oglasnoj ploči tog pravnog subjekta, te publikacijama čiji je nakladnik HZTA.

Značenje pravnog vrela ima i svaki drugi propis (kako zakonske, tako i podzakonske razine) koji se, bilo izravno bilo neizravno, bavi pitanjima sporta i građanskopravne odgovornosti. Ono što je vrlo značajno naglasiti je i uloga znanosti ${ }^{23}$ (koja djeluje snagom argumenta) kao (makar i neformalnog) vrela prava sui generis. Bitno je naglasiti i ulogu sudske prakse kao vrela prava ${ }^{24}$ sui generis, naglašavajući pri tome ogromnu ulogu ne samo redovnih (državnih) sudova, nego i posebnog specijaliziranog međunarodnog sportskog suda - arbitraže koju je osnovao Međunarodni olimpijski odbor i ima sjedište u Švicarskoj, Lausanne (CAS-TAS ${ }^{25}$ ) i njegove prakse ${ }^{26}$. Budući je moguće pravnu zaštitu protiv odluke CAS-TAS tražiti i pred švicarskim državnim sudom (obzirom na sjedište CAS TAS u Lausanne, gradu u Švicarskoj) ili bilo kojim državnim sudom u državi gdje je sjedište nekog međunarodnog tijela, status pravnog vrela dobiva i državno pravo te države ${ }^{27}$. Pri tome treba naglasiti da sudska praksa (uključujući i ustavnosudsku), djeluje snagom argumenta, ali i ,za razliku od znanosti, argumentom snage, obzirom na to da viši sudovi imaju ovlast nametnuti svoje pravne stavove nižima. Iako je Republika Hrvatska i prije stjecanja punopravnog članstva u EU imala obveze preuzete Zakonom o potvrđivanju Sporazuma o stabilizaciji i pridruživanju između Republike Hrvatske i europskih zajednica i njihovih država članica ${ }^{28}$ te su obveze od 01.07.2013. kao dana stjecanja punopravnog članstva u EU još ne samo jače nego i daleko konkretnije i uopće različiti akti koji čine ono što se obično naziva europska pravna stečevina ili acquis communautaire.

U svrhu lakšeg praćenja teksta u nastavku citiramo ključne pravne norme hrvatskog pravnog okvira.

22 Ovo ni na koji način ne mijenja činjenicu da je bitan dio borbe protiv dopinga to što je provode neovisne institucije, na čelu s međunarodnim olimpijskim odborom.

23 Namjerno se nismo ograničili na pravnu znanost, kako se to uobičajeno ili barem najčešće radi.

24 Vidjeti vrlo dobru doktorsku disertaciju pod naslovom Sudska presuda kao izvor prava - Budimir Košutić, Univerzitet u Beogradu, 1973. god. (171.stranica). Vidjeti i drugu, bitno noviju, pod naslovom Argumentacija u odlukama hrvatskih sudova, Pravni fakultet Sveučilišta u Splitu, Split, svibanj 2003. (223. stranice).

25 TRIBUNAL ARBITRAL DU SPORT - COURT ARBITRATION FOR SPORT. Vidjeti više na: www. tas-cas.org.

26 Upravo na dan predaje konačne verzije ovog teksta je objavljena najnovija odluka toga suda, odluka koja je prilično revolucionarna jer je poništila odluku kojom je MOO doživotno suspendirao veliki broj ruskih sportaša i praktično im omogućio nastup u Pjongčangu 2018., ali i otvorio vrata nizu parnica jer je to odlučeno tjedan dana prije otvorenja i veliko je pitanje je li uopće tehnički moguće u tom roku pravilno reagirati i što bi uopće bila pravilna reakcija.

27 Po nekima, obzirom na to da CAS ima i dva decentralizirana i praktično samostalna ureda (jedan je: Oceania, Level 28, Deutsche Bank PlaceCorner Hunter \& Phillip Streets AUS - Sydney NSW 2000, drugi je Sjeverna Amerika, International Centre for Dispute Resolution (ICDR)/ American Arbitration Association (AAA) 120 Broadway, US - New York, NY 10271) došlo bi u obzir i pravo država tih sjedišta.

28 Zakonom o potvrđivanju Sporazuma o stabilizaciji i pridruživanju između Republike Hrvatske i europskih zajednica i njihovih država članica, NN Međunarodni ugovori 14/01- dalje:: ZSSP ili Zakon o stabilizaciji. 
Dr.sc. Blanka Kačer: O slučaju Marije Šarapove (u svezi hrvatskog pravnog okvira odštetne... Zbornik radova Pravnog fakulteta u Splitu, god. 55, 2/2018., str. 369.- 384.

Zakon o obveznim odnosima - ZOO

Prava osobnosti

Članak 19.

(1) Svaka fizička i pravna osoba ima pravo na zaštitu svojih prava osobnosti pod pretpostavkama utvrđenim zakonom.

(2) Pod pravima osobnosti u smislu ovoga Zakona razumijevaju se prava na život, tjelesno i duševno zdravlje, ugled, čast, dostojanstvo, ime, privatnost osobnog $i$ obiteljskog života, slobodu i dr.

(3) Pravna osoba ima sva navedena prava osobnosti, osim onih vezanih uz biološku bit fizičke osobe, a osobito pravo na ugled i dobar glas, čast, ime, odnosno tvrtku, poslovnu tajnu, slobodu privređivanja $i \mathrm{dr}$.

Glava IX.

IZVANUGOVORNI OBVEZNI ODNOSI

Odjeljak 1 .

PROUZROČENJE ŠTETE

Odsjek 1.

OPCA NAČELA

Pretpostavke odgovornosti

Članak 1045.

(1) Tko drugome prouzroči štetu, dužan je naknaditi je ako ne dokaže da je šteta nastala bez njegove krivnje.

(2) Predmnijeva se obična nepažnja.

(3) Za štetu od stvari ili djelatnosti od kojih potječe povećana opasnost štete za okolinu odgovara se bez obzira na krivnju.

(4) Za štetu bez obzira na krivnju odgovara se i u drugim slučajevima predviđenim zakonom.

Šteta

Članak 1046.

Šteta je umanjenje nečije imovine (obična šteta), sprječavanje njezina povećanja (izmakla korist) i povreda prava osobnosti (neimovinska šteta).

Zahtjev da se ukloni opasnost štete

Članak 1047.

(1) Svatko može zahtijevati od drugoga da ukloni izvor opasnosti od kojega prijeti znatnija šteta njemu ili drugome, kao i da se suzdrži od djelatnosti od koje proizlazi uznemirivanje ili opasnost štete, ako se uznemirivanje ili šteta ne mogu spriječiti odgovarajućim mjerama.

(2) Sud će na zahtjev zainteresirane osobe narediti da se poduzmu odgovarajuće mjere za sprječavanje nastanka štete ili uznemirivanja ili da se ukloni izvor opasnosti, na trošak posjednika izvora opasnosti, ako ovaj sam to ne učini.

(3) Ako šteta nastane u obavljanju općekorisne djelatnosti za koju je dobiveno odobrenje nadležnog tijela, može se zahtijevati samo naknada štete koja prelazi uobičajene granice (prekomjerna šteta). 
Dr.sc. Blanka Kačer: O slučaju Marije Šarapove (u svezi hrvatskog pravnog okvira odštetne... Zbornik radova Pravnog fakulteta u Splitu, god. 55, 2/2018., str. 369.- 384.

(4) Ali se u tom slučaju može zahtijevati poduzimanje društveno opravdanih mjera da se spriječi nastupanje štete ili da se ona smanji.

Zahtjev da se prestane s povredom prava osobnosti

Članak 1048.

Svatko ima pravo zahtijevati od suda ili drugoga nadležnog tijela da naredi prestanak radnje kojom se povređuje pravo njegove osobnosti i uklanjanje njome izazvanih posljedica.

Odsjek 2.

ODGOVORNOST PO OSNOVI KRIVNJE

Postojanje krivnje

Članak 1049.

Krivnja postoji kad je štetnik prouzročio štetu namjerno ili nepažnjom. POPRAVLJANJE ŠTETE

1. Popravljanje imovinske štete

Uspostava prijašnjeg stanja i naknada u novcu

Članak 1085.

(1) Odgovorna osoba dužna je uspostaviti stanje koje je bilo prije nego što je šteta nastala.

(2) Ako uspostava prijašnjeg stanja ne otklanja štetu potpuno, odgovorna osoba dužna je za ostatak štete dati naknadu u novcu.

(3) Kad uspostava prijašnjeg stanja nije moguća, odgovorna je osoba dužna isplatiti oštećeniku odgovarajući iznos novca na ime naknade štete.

(4) Naknada u novcu dosudit će se oštećeniku ako on to zahtijeva, a okolnosti danog slučaja ne opravdavaju uspostavu prijašnjeg stanja.

2. Obujam i visina imovinske štete

Obična šteta i izmakla korist

Članak 1089.

(1) Oštećenik ima pravo kako na naknadu obične štete, tako i na naknadu izmakle koristi.

(2) Visina naknade štete određuje se prema cijenama u vrijeme donošenja sudske odluke, osim slučaja kad zakon određuje što drugo.

(3) Pri ocjeni visine izmakle koristi uzima se u obzir dobitak koji se mogao osnovano očekivati prema redovitom tijeku stvari ili prema posebnim okolnostima, a čije je ostvarenje spriječeno štetnikovom radnjom ili propuštanjem.

(4) Kad je stvar uništena ili oštećena kaznenim djelom učinjenim namjerno, sud može odrediti visinu naknade prema vrijednosti koju je stvar imala za oštećenika. 4. Naknada imovinske štete u slučaju povrede časti i širenja neistinitih navoda Članak 1098.

(1) Tko drugom povrijedi čast, iznosi ili prenosi neistinite navode o njegovoj prošlosti, znanju, sposobnosti, ili o čemu drugome, a zna ili bi morao znati da su neistiniti, i time mu prouzroči imovinsku štetu, dužan je naknaditi je.

(2) Ali ne odgovara za prouzročenu štetu onaj tko učini neistinito priopćenje o drugome ne znajući da je ono neistinito, ako je on ili onaj komu je priopćenje učinio imao u tome ozbiljnog interesa. 


\section{Popravljanje neimovinske štete}

Objavljivanje presude ili ispravka

Članak 1099.

U slučaju povrede prava osobnosti oštećenik može zahtijevati, na trošak štetnika, objavljivanje presude, odnosno ispravka, povlačenje izjave kojom je povreda učinjena, ili što drugo čime se može ostvariti svrha koja se postiže pravičnom novčanom naknadom.

Pravična novčana naknada

Članak 1100.

(1) U slučaju povrede prava osobnosti sud će, ako nađe da to težina povrede $i$ okolnosti slučaja opravdavaju, dosuditi pravičnu novčanu naknadu, nezavisno od naknade imovinske štete, a $i$ kad nje nema.

(2) Pri odlučivanju o visini pravične novčane naknade sud će voditi računa o jačini i trajanju povredom izazvanih fizičkih boli, duševnih boli i straha, cilju kojemu služi ta naknada, ali i o tome da se njome ne pogoduje težnjama koje nisu spojive sa njezinom naravi i društvenom svrhom.

(3) Za povredu ugleda i drugih prava osobnosti pravne osobe sud će, ako procijeni da to težina povrede $i$ okolnosti slučaja opravdavaju, dosuditi joj pravičnu novčanu naknadu, nezavisno od naknade imovinske štete, a i kad nje nema.

\section{ANALIZA PROBLEMA}

\section{III.1. ČINJENIČNO STANJE}

Činjenice su potpuno jasne. Pored velikog niza onih koji su svoj negativni stav iskazivali, bilo javno i anonimno, bilo potajno, bilo je i onih koji su to radili javno, ne sakrivajući pri tome svoj identitet. Pri tome je bit izjava praktično uvijek isti (dok se o motivima možda može i drukčije raspravljati, možda i tražeći neke osobno loše odnose, želju za manjom konkurencijom i drugo) - neprihvatljivo je nekoga tko se ogriješio o antidoping pravila nakon isteka kazne na bilo koji način favorizirati, a posebno ne na način da se toj osobi dodjeljuju pozivnice za turnire i da u rasporedu igranja dobiva najbolja igrališta ${ }^{29} \mathrm{i} / \mathrm{ili}$ najbolje termine ${ }^{30}$. U jednom od najizravnijih i objektivno najružnijih istupa jedna igračica je izravno usporedila Mariju Šarapovu s nekad velikim prvakom u biciklizmu koji je (unatoč tome što je sve otkriveno tek nakon njegovog javnog priznanja u TV emisiji koja je emitirana „in vivo“ i koje

29 Ili da nikada ne dobije ona najgora. Tako je npr. igralište broj 2 na najvećem svjetskom turniru poznato kao „groblje favorita,“ tako da oni koji su favoriti u pravilu ne žele to igralište. Pri tome uopće nje od značenja što je tu objektivno, a što subjektivno.

30 Možda su najdrastičniji primjeri s Roland Garros-a gdje je zbog podloge (zemlja) trajanje susreta daleko duže nego ako je podloga trava ili beton, a vrijeme tog turnira „pada“ u doba velikih vrućina (lipanj) u Parisu i unatoč tome susreti počinju u 11 sati. Nije potrebno posebno znanje o sportu općenito i o tenisu da bi se usporedbom uvjeta u 11 sati i predvečer u 18 vidjela ogromna razlika. 
priznanje je po naravi stvari mogao i izbjeći) na globalnoj razini postao simbol prijevare i izigravanja anti-doping pravila (Lance Armnstrong) ${ }^{31}$.

Organizatori turnira u Stuttgartu, Madridu i Rimu su, nakon što je Marija Šarapova izdržala kaznu, njoj vrlo rado dali pozivnicu. Pri tome je sasvim jasno da nisu tako postupili zato što je osobno simpatiziraju, što se zalažu za doping ili što su protiv anti-doping aktivnosti, razlog njihove odluke je (očito) bio vrlo prozaičan - smatrali su (i pri tome bili u pravu) da će njihov turnir biti posjećeniji od strane publike, praćeniji od strane medija i općenito interesantniji za sponzore s Marijom Šarapovom, nego bez nje. Što se najvećih (Grand Slam) turnira tiče, na njima nije bez pozivnice mogla nastupiti ni u kvalifikacijama, jer je prije prvog došla do 148. mjesta na rang listi, propustila je Roland Garros (očito zato jer nije dobila pozivnicu), dok u Wimbledon-u nije nastupila zbog ozljede ${ }^{32}$. Na US Open je nastupila s pozivnicom za glavni turnir na kojemu je ostvarila tri pobjede i izgubila $\mathrm{u}$ četvrtom kolu, što je značilo plasman u osminu finala - među 16 najboljih. Nedugo nakon toga osvojila je i prvi turnir nakon duge pauze i i 2018. god je započela plasmanom unutar TOP 60 na WTA ljestvice, tako da pitanje pozivnica više nije aktualno (sve igračice koje se na rang listi nalaze do 100. mjesta imaju osiguran ulazak u glavni turnir svakog Grand Slam turnira ${ }^{33}$ ).

Otkada se Marija Šarapova „vratila na teren“, ali čak i prije toga, već od kada je bilo jasno da će nastupati odmah nakon isteka kazne, pod udarom je žestokih kritika tenisačica kojima nije jasno (ili jest jasno, ali i neprihvatljivo) zašto ima privilegiran status među organizatorima turnira, iako je koristila zabranjenu supstancu meldonij, a samim time i grubo kršila anti-doping pravila. U kritici su se istakle Eugenie Bouchard, Kristina Mladenović, Caroline Wozniacki i Agnieszka Radwanska, ali najžešće je istupila naša Mirjana Lučić, usporedivši je s najpoznatijim sportskim varalicom $^{34}$. Donedavna igračica broj 1 na WTA rang listi (sada broj 2) Simona Halep ${ }^{35}$ je bila daleko suzdržanija izjavljujući kako ona ne bi dala pozivnicu Mariji Šarapovoj, ali ne može ni suditi o odluci organizatora koji imaju pravo donijeti tu odluku. Nekadašnja broj 1 na WTA Kim Clijsters je izjavila kako je Marija Šarapova odslužila svoju kaznu i kako zbog toga ne vidi spornim pozivnice. Na kraju, WTA čelnik Steve Simon je stao u zaštitu Marije Šarapove i prava organizatora da joj daju pozivnice ${ }^{36}$.

31 Prema medijima upravo takvu izjavu je dala Mirjana Lučić: „, Novac i sve oko njega govore sami za sebe. Možda bi trebali dati pozivnicu i Lanceu Armstrongu, čovjek je nekoliko puta osvojio Tour de France. Kakva je razlika između Armstronga i Šarapove?" - internet izdanje Sportskih novosti od 17.06.2017., autor Dean Bauer.

32 Ostalo je otvoreno pitanje bi li tamo dobila pozivnicu i bi li to bila pozivnica za kvalifikacije ili glavni turnir.

33 A broj bolesnih, ozlijeđenih i spriječenih samo čini ovaj broj (u tenisu se to označava kao cut off znači broj na rang listi posljednjeg igračice koja je izravno ,ušla“ u glavni turnir.

34 Vidjeti bilješku broj 8.

35 Globalno možda najviše poznata po tome što se podvrgnula estetskoj operaciji - zahvat smanjenja grudi, s objašnjenjem da su joj velike grudi otežavale kretanje. Sada kada je bila i broj 1 i kada je stalni član TOP 5 na WTA, tko joj može kazati da nije bila u pravu ?

$36 \mathrm{http}: / /$ www.bbc.com/sport/tennis/39711325, preuzeto 01.02.2018. u 18,00. 
Inače, makar i ne bilo odlučno, treba kazati kako je Marija Šarapova kažnjena zbog toga što je uzela nedopušteno sredstvo meldonij, ali ipak pod dosta specifičnim uvjetima koji joj daleko više idu in favorem, nego na štetu. Naime, ona je sredstvo koje sadrži meldonij uzimala u kontunitetu desetak godina, dok meldonij nije bio zabranjen. Unatoč tome što je lista na kojoj se kao novota nalazio i meldonij objavljena bitno prije stupanja na snagu nove liste, Marija Šarapova, niti oni koje se umjesto nje i za nju trebaju skrbiti o svemu (pa i o listi zabranjenih sredstava), nisu obavili svoj posao i ona je preparat nastavila uzimati i nakon što je postao zabranjen. Dodatno, meldonij, po svim dostupnim podacima, apsolutno ne doprinosi rezultatima u sportu kao što je tenis.

\section{III.2. PRAVNA ANALIZA}

\section{III.2.1. OPĆENITO O ŠTETI I ODGOVORNOSTI ZA ŠTETU (IN ABSTRACTO)}

Odgovornost za štetu je obveznopravni (ugovorni ili izvanugovorni) odnos u kojem je jedna strana dužna drugoj strani popraviti štetu, a druga je od prve ovlaštena zahtijevati taj popravak ${ }^{37}$. Odgovornost za štetu nastaje pod pretpostavkom da je osoba odgovorna za štetu (štetnik) počinila protupravnu štetnu radnju zbog koje je nastala šteta osobi koja traži popravak štete (oštećenik) i ako postoji uzročna veza između štetne radnje i štete kao posljedice. Sve navedene pretpostavke moraju biti ispunjene kumulativno. Tako su pretpostavke odgovornosti za štetu (pored subjekata - štetnika i oštećenika):

A/ štetna radnja štetnika, B/ šteta, C/ uzročna veza između štetne radnje i štete (kauzalni neksus) i D/ protupravnost ${ }^{38}$.

A Štetna radnja je svaka radnja, činidba (commissio) ili propust (omissio) štetnika kojom se oštećeniku nanosi šteta. Javlja se kao građanski delikt i povreda ugovornog odnosa. Kod građanskog delikta (deliktna odgovornost) između stranaka prethodno ne postoji ugovorni odnos. Prema odredbi članka 8. ZOO svatko je dužan uzdržati se od postupka kojim se može drugome prouzročiti šteta (neminem laedere). Utoliko svako postupanje (činidba ili propust) kojim se drugome prouzrokuje šteta, a koje postupanje nije povreda ranije preuzete ugovorne obveze, predstavlja odnosno može predstavljati građanski delikt. Između štetnika i oštećenog, u ovom slučaju, nastaje izvorna i samostalna obveza odgovornosti za štetu. O povredi ugovornog odnosa (ugovorna odgovornost) govorimo u okolnostima kada stranka svojim postupanjem (činidba ili propust) vrijeđa (ne poštuje) postojeću ugovornu obvezu. Sukladno odredbi članka 9. ZOO sudionici u obveznom odnosu dužni su

37 Vidjeti tako u: Petar Klarić - Martin Vedriš, Građansko pravo, Narodne novine, Zagreb, kolovoz 2008. god. str. 583

38 Vidjeti tako u: Hrvoje Kačer - Ante Perkušić, u: Vilim Gorenc et alt., Komentar Zakona o obveznim odnosima, RRIF, Zagreb, listopad 2005., str. 1605. 
ispuniti svoju obvezu i odgovorni su za njezino ispunjenje, pa kada dužnik ne ispuni svoju obvezu ili zakasni s njenim ispunjenjem, vjerovnik je ovlašten zahtijevati i popravljanje štete koju je zbog tog pretrpio (članak 342. ZOO). Sukladno odredbi članka 6 ZOO zabranjeno je ostvarivanje prava iz obveznog odnosa suprotno svrsi zbog koje je ono propisom ustanovljeno ili priznato. Utoliko obveznopravni odnos može povrijediti i vjerovnik obveznopravnog odnosa. U literaturi ${ }^{39}$ se kao specifičan oblik izvanugovorne odgovornosti navodi i predugovorna odgovornost (strana koja je pregovarala ili prekinula pregovore suprotno načelu savjesnosti i poštenja članak 251 u svezi s odredbom članka 4 ZOO). Na ovu odgovornost odgovarajuće se primjenjuje normativa o deliktnoj odgovornosti. Zakon sadrži posebne odredbe glede popravljanja štete iz osnova povrede ranije preuzete ugovorne obveze, tj. ugovornoj odgovornosti (članak 342-349). Odredbe o izvanugovornoj (članak 1045-1110 ZOO) odgovornosti za štetu, kao opće odredbe odgovornosti za štetu, primjenjuju se i na ugovornu odgovornost, ukoliko za ugovornu odgovornost nije što drugo propisano (čl. 349 ZOO).

B Kako smo naveli, šteta je umanjenje nečije imovine (obična šteta), spriječavanje njezina povećanja (izmakla korist) i povreda prava osobnosti (neimovinska šteta). Uočljiva je bitna razlika između ove i ranije zakonske definicije na planu neimovinske (ranije nematerijalne) štete, prema kojoj je šteta bila definirana kao umanjenje nečije imovine (obična šteta), spriječavanje njezina povećanja (izmakla korist $)^{40}$ i nanošenje nekome psihičkog ili fizičkog straha ili bola. Razlika ni u kojem slučaju ne smije biti shvaćena kao formalna ili samo terminološka.

C Da bi došlo do odgovornosti za štetu između štetne radnje i štete mora postojati uzročna veza - kauzalni neksus. Šteta se mora javljati baš kao posljedica štetne radnje. Šteta obično nastupa kao posljedica više uzroka, pa je u okolnostima svakog slučaja potrebno cijeniti onaj uzrok koji je pravno relevantan. To je uzrok koji je tipičan (prema životnom iskustvu ili pravilima struke, uobičajenom životnom tijeku stvari) za određenu štetnu posljedicu. Tako je prema sudskoj praksi pravno relevantni uzrok štete onaj štetni događaj čijem redovitom učinku odgovara konkretna šteta. Na oštećeniku je uvijek ${ }^{41}$ teret dokaza glede uzročne veze, zato jer se ista ne predmnijeva. Međutim, navedeno ni u kojem slučaju ne znači u odnosu na neku štetu nije moguće postojanje više uzroka i više kauzalnih neksusa. Ako se to dogodi potrebno je utvrditi doprinos svakog pojedinog uzroka (npr. prometna nesreća i osobni - obiteljski gubitak), a ako to nije moguće treba primijeniti propisanu kako predmnjevu tako i solidarnost.

D O protupravnosti govorimo kada je povrijeđena neka pravna norma. Pri tom nije riječ samo o normama građanskog prava jer i ponašanje suprotno normama drugih pravnih područja može dovesti do štete. Prema načelnoj odredbi članka 8. ZOO svatko je dužan uzdržati se od postupka kojim se može drugom prouzročiti šteta

39 Vidjeti u: Ivica Crnić, Odštetno pravo, Faber \& Zgombić Plus d.o.o., Zagreb, 2004 god., str. 4.

40 Glede prva dva dijela nije došlo do promjene.

${ }^{41}$ Naš zakonodavac je odredbom čl. 1063. ZOO odstupio od ovog rješenja kod odgovornosti od opasne stvari i opasne djelatnosti na način da je propisana (oboriva) predmnjeva uzročnosti. 
(neminem leadere), dok je odredbom članka $1045 \mathrm{ZOO}$ normirana obveza štetnika da naknadi štetu koju je prouzročio. Utoliko, da bi došlo do odgovornosti za štetu, nije potrebno da pravo, koje je u pojedinom slučaju povrijeđeno, izričito predviđa odgovornost za štetu. Isto tako u okolnostima protupravnog ponašanja s kojim u uzročno posljedičnoj vezi nije nastupila šteta neće biti ispunjene pretpostavke odgovornosti za štetu. U ovom slučaju osoba koja je povrijedila pravnu normu može odgovarati npr. kazneno i/ili za prekršaj, ali kako u pravno relevantnoj uzročno posljedičnoj vezi s njegovim postupanjem nije nastupila šteta (njegovim postupanjem nije povrijeđeno subjektivno pravo ili pravom zaštićeni interes druge osobe) neće biti ostvarene pretpostavke odgovornosti za štetu. Da li u pojedinom slučaju postoji protupravnost kao pretpostavka odgovornosti za štetu, ocjenjuje se ovisno o tom traže li se za protupravnost samo objektivni ili subjektivni elementi protupravnosti. Kad se kod protupravnosti traže samo objektivni elementi, od odlučnog značaja je činjenica da je štetnik svojim postupanjem povrijedio normu objektivnog prava, dok je odnos počinitelja prema radnji i nanesenoj šteti (krivnja) irelevantan. Subjektivni elementi protupravnosti izražavaju se krivnjom počinitelja. U ovom slučaju nije dovoljna činjenica da je štetnik svojim postupanjem povrijedio normu objektivnog prava, već se zahtijeva i određeni stupanj štetnikove krivnje.

\section{III.2.2. O ODŠTETNOJ ODGOVORNOSTI IN CONCRETO}

U našem (dijelom) hipotetičnom primjeru ili slučaju jasno je tko je u ulozi oštećenika. To je u prvom redu Marija Šarapova kao tenisačica koju se javno optužuje - tereti da je povlaštena od organizatora, ponovno podsjećajući sve koji su zaboravili ili nisu uopće znali na doping skandal radi kojeg je kažnjena i koju kaznu je odslužila. Međutim, kao oštećenik se (potencijalno) mogu pojaviti i druge pravne i/ili fizičke osobe. Tako je npr. svaki sponzor Marije Šarapove potencijalno oštećenik ako se o njoj loše govori i piše, jer to može loše djelovati na prodaju proizvoda i usluga čije je ona ,zaštitno ime“. Što se pak fizičkih osoba tiče, one mogu imati pravni položaj kao i pravne (glede komercijalnih odnosa), ali i biti povezani s Marijom Šarapovom na način koji je možda najlakše opisati laičkom složenicom „s kim si takav si“. Što se tiče štetnika, to su svi (bilo da se radi o pravnim ili fizičkim osobama) oni koji su izjavama u medijima i na drugi način djelovali s ciljem sprječavanja davanja pozivnica za turnire Mariji Šarapovoj i uopće prikazujući je kao tenisačicu kojoj se (neopravdano) daju razne pogodnosti koje ne bi smjela dobiti zato jer je imala doping skandal radi kojega je i kažnjena iako je kaznu izdržala.

\section{A) Štetna radnja štetnika}

Vrlo je jasno da se štetna radnja štetnika sastoji i (manje ili više) javnom zalaganju i stvaranju pritiska na organizatore teniskih turnira da se Mariji Sarapovoj ne daju pozivnice za turnire (dodatno i na turnirima ne osiguravaju elitni termini za igru) $\mathrm{i}$ to zato što je bila kažnjena u doping skandalu. 


\section{B) Šteta}

Kako smo već naveli, šteta može biti stvarna šteta (umanjenje imovine), izmakla dobit i povreda prava osobnosti. Moguće su baš sve navedene vrste štete.

U odnosu na imovinsku štetu treba uputiti na posebnu odredbu sadržanu u čl. 1098 st.1. Zakona o obveznim odnosima prema kojoj „Tko drugom povrijedi čast, iznosi ili prenosi neistinite navode o njegovoj prošlosti, znanju, sposobnosti, ili o čemu drugome, a zna ili bi morao znati da su neistiniti, i time mu prouzroči imovinsku štetu, dužan je naknaditi je." stvari su potpuno jasne. Svačija čast je u svakom slučaju povrijeđena (daleko više nego nečijom pljuskom ${ }^{42}$ ) ukoliko ga (je) se u javnosti podsjeća na tek izdržanu kaznu, povezuje sa notornim negativcima itd. za hrvatsko pozitivno pravo, kada je očito došlo do povrede časti nije ni potrebno istraživati jesu li eventualno neistiniti navodi o njezinoj prošlosti, ili o čemu drugome u svezi dopinga, kao ni da li zna ili bi morala znati da su ti navodi neistiniti. Jednako tako nije potrebno ni primjenjivati stavak drugi istog članka koji razrađuje dio prvog stavka koji se odnosi na neistinite navode.

Naime i ako igračica mora doći već u kvalifikacije (umjesto tek na glavni turnir), to su dodatni troškovi boravka na turniru (smještaj, hrana....), dakle nastala joj je stvarna šteta (umanjenje imovine). U smislu izmakle dobiti, ako igračica izgubi u kvalifikacijama, to znači da, ako se ne plasira u glavni turnir, gubi (barem) iznos koji bi joj inače pripao već samo pojavljivanjem u prvom kolu glavnog turnira (na najvećim, Grad Slam turnirima to su iznosi od preko 30.000,00 US \$ koji se dobivaju bez ikakvih daljnjih uvjeta). Dodatno, svaki uspjeh na turniru (a definitivno ga je lakše postići ako se izbjegnu kvalifikacije) znači i bonus kod sponzora, bilo izravno (temeljem nastupa u skladu s ugovorom sponzora i igračice koji to honorira, makar je moguć i ugovor bez takve odredbe), bilo neizravno na način da se za nastup i rezultat dobiju bodovi koji znače pomak na (WTA) rang listi koji znači ulazak na turnir i bez pozivnice, a može značiti i dodatan honorar od sponzora sukladno ugovoru, ali i nove moguće sponzore koji ulažu u igračice koje su plasirane najmanje na određeno mjesto, a one ispod toga ih ne zanimaju.

Pravno je daleko najintrigantnija i s najviše mogućih dvojbi povreda prava osobnosti u ovom konkretnom slučaju. Zakonska formulacija našeg Zakona o obveznim odnosima koja primjerično (exempli causa) definira prava osobnosti kao objekt povrede (tjelesno i duševno zdravlje, ugled, čast, dostojanstvo, ime, privatnost osobnog i obiteljskog života...) definitivno uključuje (duboku) povrijeđenost javnim i drugim prozivkama koje uključuju i podsjećanje na izdržanu kaznu zbog doping skandala i povezivanje sa notornim negativcima (glede dopinga to je izvan svake sumnje Lance Armstrong). Pri tome je vrlo značajno po intenzitet povrede (posljedično i po visinu štete) ukazati i na to da se za kršenje anti-doping pravila odgovara i bez krivnje (koja je više kriterij za odmjeravanje kazne između

42 , Povredom časti, pod čim se podrazumijeva usmenu ili pisanu izjavu ili ponašanje (npr. pljuska) neke osobe u odnosu na drugu, što za posljedicu izaziva omalovažavanje ili nepoštivanje (u kaznenom pravu uvreda)." Vidjeti tako u: Hrvoje Kačer - Ante Perkušić, u: Vilim Gorenc et alt., Komentar Zakona o obveznim odnosima, RRIF, Zagreb, listopad 2005. , str. 1710.. 
maksimuma i minimuma), a po naravi stvari krivnja je prilično razmjerna količini opravdane neugode zbog samog (u ovom slučaju doping) skandala, a obrnuto razmjerna količini neugode. Ne dirajući uopće u postojanje odluke o, sada već izdržanoj, kazni, treba naglasiti da su okolnosti konkretnog slučaja iznimno blage i svakako idu in favorem tenisačice - ona je taj lijek ili preparat koji sadrži meldonij već ranije (dok nije bio zabranjen) godinama uzimala i zapravo je prije počinila grijeh nečinjenja (propust uočiti promjenu statusa meldonija na način da je od dopuštenog došao na listu zabranjenog), nego činjenja (uzimanja). At last but not least, nije nebitno ni to da meldonij u teniskom sportu ne znači nekakvo povećanje sposobnosti.

Bitno je spomenuti i još jedan jedan apsurd - što se oštećenik ,,bolje drži“, ta njegova ili njezina snaga objektivno najviše ide u prilog štetniku. To isto vrijedi i za slučajeve kada, unatoč velikim stvarnim tegobama, vanjski istupi iste negiraju Marija Sarapova je tako u jednom istupu kazala kako njoj uopće ne bi smetalo igrati ni na parkiralištu ni u bilo koje doba dana.

C) Uzročna veza između štetne radnje i štete (kauzalni neksus)

Kauzalni neksus u konkretnom slučaju, načelno ne bi trebao biti posebno sporan. Međutim, to je ipak tako više kod povrede prava osobnosti, a manje kod stvarne štete i izmakle dobiti.

U slučajevima stvarne štete i izmakle dobiti problem može biti u dvojbi bi li i bez pritiska drugih tenisačica u javnosti na organizatore, organizator u konkretnom slučaju dao ili ne bi dao pozivnicu. Obzirom na činjenicu da je teret dokaza u parničnom postupku na tužitelju (a u tom postupku će za odbijanje tužbenog zahtijeva u pravilu, potpuno sigurno, čak i ako nije istinit, biti dovoljan već negativan dokaz iskaz organizatora turnira da im ta opcija uopće nije bila u razmatranju) biti će potrebno dokazati da je baš opisani pritisak spriječio dobivanje pozivnice, odnosno da bi pozivnica baš njoj bila dodijeljena u slučaju da je izostao pritisak na organizatore. U slučaju da je pozivnica (unatoč pritisku) dodijeljena ova šteta neće doći u obzir.

Glede povrede prava osobnosti kao prvo treba naglasiti da je ta šteta moguća u obje moguće situacije, dakle i onoj kada je do davanja pozivnice došlo i kada do toga nije došlo. Drugim riječima, davanje ili nedavanje pozivnice nisu uvjeti za ovu štetu. Međutim, potencijalni problem načelno može biti u tome što postoji više konkurentskih kauzalnih neksusa (uzroka) u odnosu na ključni uvjet - nastalu štetu. Tako je npr. moguće da je osobnost oštećenika povrijeđena i nečijom štednom radnjom, ali i razvodom koji se događa u istom vremenu i/ili sukobom sa nekom trećom osobom, prometnom nesrećom koja pored tjelesnih povreda uzrokuje i povredu prava osobnosti, sukobima sa zakonom (kaznene, porezne ili bilo koje druge naravi). Mi nemamo baš nikakvog podatka da je u konkretnom slučaju nešto takvo postojalo, ali ako bi postojalo, onda bi se u postupku moralo precizno utvrditi sudjelovanje pojedinog uzroka u šteti. Niti jedan propis, kao ni bilo koji logični argument, ne idu in favorem zaključka da od više uzroka koji udovoljavaju uvjetu kauzalnog neksusa u odnosu na konkretnu štetu treba izdvojiti samo jedan. 


\section{D) Protupravnost}

Ovaj dio je možda najdvojbeniji za dokazivanje. Naime, ovdje je s jedne strane pravo (svih) oštećenica izraziti svoje mišljenje i nejavno i javno, a to mišljenje ne mora, ni u kojem slučaju, biti pozitivno. S druge strane je pravo svake osobe biti slobodna od bilo kakvih uvreda, kako javnih tako i nejavnih. Ako se prednost da pravu na izražavanje svojeg mišljenja, ma kakvo ono bilo, onda ni Marija Šarapova ne bi imala pravo na pravnu zaštitu. A contrario, ako se Mariji Šarapovoj prizna pravo na pravnu zaštitu, negira se pravo na iskazivanje mišljenja. (Prethodno) pitanje koje treba riješiti prije zauzimanja stava je analiza jesu li štetnice u iskazivanju svojeg mišljenja pretjerale ili nisu. Ako jesu, to bi značilo da su prešle crtu koja dijeli ponašanje sukladno pravo od onog protupravnog. Ako nisu, ostale su u dozi ponašanja sukladnog pravu.

Osnovno je provjeriti je li moguće pronaći neko kompromisno rješenje, u kojemu se može očuvati pravo na izražavanje mišljenja, a istodobno da se ne ugrozi integritet Marije Šarapove i onda po tom kriteriju odlučiti radi li se ili ne radi o protupravnosti. Po našem mišljenju, to rješenje je moguće. Pravi primjer je izjava Simone Halep koju smo citirali i koja je kazala kako ona pozivnicu ne bi dala, ali zna da je to ovlast direktora turnira i ona to poštuje. Međutim, izjava kojom se uspoređuje Marija Šarapova s Lance Armstrongom, koji je postao sinonim za najteže moguće kršitelje doping pravila, je apsolutno prešla crtu dopuštenosti i duboko zašla u zonu protupravnosti. Naime, svoj negativni stav je izrazila i Simona Halep, ali pri tome je poštovala integritet Marije Sarapove. U drugoj izjavi je to potpuno drukčije. Svoj negativni stav je druga igračica izrazila bez ikakvog obzira, pri čemu nije bez značenja ni to što joj je neposredno predstojao turnirski susret baš s Marijom Šarapovom. Po našem dubokom uvjerenju taj izostanak mjere, upravo to pretjerivanje treba izjednačiti s protupravnošću.

\section{ZAKLJUČAK}

U ovom radu smo pokušali naći rješenje jednog načelnog problema, ali uz primjenu na konkretnom (makar dijelom ${ }^{43}$ hipotetičnom) primjeru. U sučeljavanju dva neupitna prava - s jedne strane pravo (svih) izraziti svoje mišljenje, bilo nejavno, bilo javno (a to mišljenje ne mora ni u kojem slučaju biti pozitivno), s druge strane pravo svake osobe biti slobodna od bilo kakvih uvreda, kako javnih tako i nejavnih (što uključuje i iznošenje vlastitog stava koji vrijeđa drugoga) potrebno je utvrditi granicu protupravnosti, o čemu ovisi koje pravo ima prednost i koje ponašanje je, a koje nije, protupravno. U konkretnom događanju je niz poznatih tenisačica javno protestirao (i tako radio pritisak na organizatore turnira) protiv davanja pozivnica za turnire igračici koja je upravo „odslužila“ svoju kaznu u trajanju od 15 mjeseci nenastupanja na turnirima, koja kazna je posljedica toga što je zatečena u kontroli nje kao sportašice i je li ili ne uzimala neki od preparata s liste zabranjenih. Nakon

43 Hipotetično je samo smještanje događanja na područje primjene hrvatskog pozitivnog prava. 
temeljite analize zaključeno je da je umjereno iskazivanje vlastitog mišljenja samo korištenje vlastitog prava na izražavanje svojeg mišljenja kojim se ne vrijeđa tuđa čast, niti ugrožava i oštećuje tuđe pravo osobnosti. Međutim, ako se pri tome pretjeruje onda je prijeđena granica - crta koja dijeli protupravna ponašanja od onih ponašanja sukladnih pravu. U ovom drugom slučaju, ako su ispunjeni i ostali zakonski uvjeti, postoji građanskopravna odštetna odgovornost. U prvom slučaju, zato što je potrebno kumulativno ispunjenje svih uvjeta, ne postoji građanskopravna odštetna odgovornost.

\section{THE MARIJA ŠARAPOVA CASE - (RELATED TO THE CROATIAN LEGAL FRAMEWORK ON DAMAGES LIABILITY)}

Here an attempt is made to find a legal solution to a principle problem together with analysis of a concrete example. There is confrontation between two indisputable but partially mutually exclusive rights. On the one hand, freedom of speech privately and /or publicly and this opinion need not be at all positive, and on the other hand there is every individual's right to be free of any insult both private and public including expressing one's own opinion which offends another. It is necessary to establish the limit of illegality. This depends on which right takes precedence. This involves an actual event in which various female tennis players publicly protested, and in this way put pressure on tournament organizers against inviting to the tournament a female tennis player who had just finished "serving" her punishment of a 15 month ban on playing at tournaments. This punishment was the result of her being caught under inspection of her as an athlete and whether she had consumed some substances from the list of forbidden substances. After thorough analysis, it was concluded that a mild display of opinion was involved which did not in any way offend another's honour nor threaten or damage another's personality rights. However, if this were exaggerated, then the limit has been violated-a line has been crossed which divides illegal from legal behaviour. In this second case, if other legal conditions are met, there is a case for damages lability. In the first instance, because cumulative fulfilment of all conditions is necessary, no civil damages liability exists.

Key words: legal security, rule of law, equality in the eyes of the law, damages, civil liability 